Original article

https://www.journal-imab-bg.org

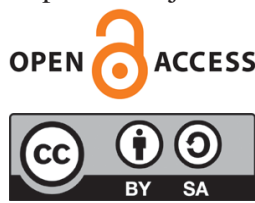

\title{
THE PRESENCE OF IL-8 GENE POLYMORPHISM AT (-251A/T) AND (-396T/G) POSITION IS RELATED WITH SUSCEPTIBILITY TO PERIODONTITIS DEVELOPMENT.
}

\author{
Antoaneta Mlachkova ${ }^{1}$, Velitchka Dosseva-Panova ${ }^{1}$, Christina Popova ${ }^{1}$, Maja \\ Kicheva ${ }^{2}$ \\ 1) Department of Periodontology, Faculty of Dental Medicine, Medical \\ University, Sofia, Bulgaria. \\ 2) PhD, biochemist, Progene Ltd., Sofia, Bulgaria.
}

\begin{abstract}
Background: Periodontitis is a chronic inflammatory disruption of the supportive periodontal tissue. It is known that the chronic periodontitis is initiated by the increased level of specific bacteria, but the progression of the disease is defined by characteristics of the host response to the bacterial load. There is evidence that individual genetic, systemic and environmental risk factors can influence the course of the disease. Some genes and intergenic relations are in connection with the modification of the periodontal disease, and so they change the clinical course, the severity and the prognosis of the decease.

Purpose: The aim of the current investigation is to establish the presence of IL-8 gene polymorphism and serum levels to IL- 8 in patients with chronic periodontitis.

Material and methods: In the recent study, 35 patients (24 females and 11 males) are included with diagnosis moderate to severe periodontitis. Periodontal important parameters such as PD, CAL and Bone loss are included. The level of IL- 8 in a patient's serum is tested by ELISA (enzymelinked immunosorbent assay). The presence of IL- 8 polymorphism in loci rs4073 (-251A/T) and rs2227307 (-396T/ $\mathrm{G})$ is established by polymerase chain reaction (PCR).

Results: The analysis of the current assay recognized a statistically significant correlation between: HI and PBIseverity and HI and BOP; a significant correlation between PBI- severity and PD average and Bone loss; the strong correlation between BOP and Bone loss; the significant correlation between $\mathrm{PD} 3-5 \mathrm{~mm}$ and $\mathrm{PD} \geq 7 \mathrm{~mm}$ and $\mathrm{CAL}$ average, also a strong correlation between PD $\geq 7 \mathrm{~mm}$ and Bone loss. The results have shown that the biggest interrelationship observed between the presence of GT/AT genotype and TT/TT genotype and distribution of PD 5-7 $\mathrm{mm}$ and PD $\geq 7$ $\mathrm{mm}(\mathrm{p}<0.09)$.

Conclusions: In the recent study have shown that by reason of the heterogeneous results achieved in the group investigated by us we can definitely support the hypothesis that the presence of allele A for rs407 $(-251 \mathrm{~A} / \mathrm{T})$ and allele $\mathrm{G}$ for rs2227307 (-396T/G) is strongly related with expression of severe periodontitis.
\end{abstract}

Keywords: gene polymorphism, interleukin-8, sus- ceptibility, periodontitis, enzyme-linked immunosorbent assay, polymerase chain reaction.

\section{INTRODUCTION:}

At present, it is known that pathogenic bacteria are the key factors for the initiation of periodontal disease, but the host response and the severity of clinical expression are largely determined by genetic susceptibility and environmental factors [1-5]. The first study of cytokines' gene polymorphisms was reported by Kornman who found a significant association between severe adult periodontitis and composite genotype, namely allele 2 of a single nucleotide polymorphism (SNP)of IL-1A+4845 and IL-1B+3954 located on chromosome2q13[6]. Following this, several studies have been conducted exploring the role of IL-1 gene polymorphisms as a severity factor in periodontitis in various population and ethnic groups [7-11]. However, there is evidence that genetic variations affect the host response by means of receptor expression and secretion of proinflammatory cytokines and chemokines measured in the crevicular fluid, such as: IL- 1ß, IL- 8, IL- 10, IL-13 and IL-17that are associated with a certain periodontal status [1219]. There is data that genetic factors are likely to be important determinants of the risk of periodontal diseases by suggesting that these diseases are polygenic rather than monogenic [20-23].

\section{AIM:}

To determine the presence of IL-8 gene polymorphism and serum levels to IL- 8 in patients with periodontitis.

\section{MATERIAL AND METHODS:}

In the recent study, 35 patients (24 females and 11 males) were included with diagnosis moderate to severe periodontitis. Periodontal important parameters such as PD, CAL and bone loss were included. The level of IL- 8 in the patient's serum was tested by ELISA (enzyme-linked immunosorbent assay). The present of IL- 8 polymorphism in loci rs4073 (-251A/T) and rs2227307 (-396T/G) was established by PCR. 
RESULTS:

The results of the current study are presented in Tables 1, 2 and 3, and Box plots 1 and 2 .

Table 1. Spearman rank order correlations (R- coefficients and p-values) among 12 markers in the studied patient group $(n=35)$.

\section{Correlations}

\begin{tabular}{|c|c|c|c|c|c|c|c|c|c|c|c|c|c|}
\hline & & Age & $\mathrm{HI}$ & PBI & BoP & $\begin{array}{l}\mathrm{PD}_{-} \\
\text {Mean }\end{array}$ & $\begin{array}{c}P \mathrm{PD} \\
<3 \mathrm{~mm}\end{array}$ & $\begin{array}{c}\mathrm{PD}= \\
3-5 \mathrm{~mm}\end{array}$ & $\begin{array}{c}\mathrm{PD}= \\
5-7 \mathrm{~mm}\end{array}$ & $\begin{array}{c}\text { PD } \\
>7 \mathrm{~mm}\end{array}$ & $\begin{array}{c}\mathrm{CAL}, \\
\mathrm{mm}\end{array}$ & $\begin{array}{c}\text { Bone loss, } \\
\mathrm{mm}\end{array}$ & IL 8 \\
\hline \multirow[t]{3}{*}{ Age } & Pearson & 1 & 051 & ,039 &,- 057 &,- 060 & 027 & 009 ب r &,- 076 & ,080 & 034 & ,054 & $-.337^{*}$ \\
\hline & Sig. (2-tailed) & & 769 & ,825 & ,744 & ,732 & 876 & ,957 & 664 & 649 & 845 & ,757 & 048 \\
\hline & $\mathrm{N}$ & 35 & 35 & 35 & 35 & 35 & 35 & 35 & 35 & 35 & 35 & 35 & 35 \\
\hline \multirow[t]{3}{*}{$\mathrm{HI}$} & $\begin{array}{l}\text { Pearson } \\
\text { Correlation }\end{array}$ & ,051 & 1 & $-.589^{* *}$ & $-.853^{\text {** }}$ &,- 262 & 264 & , 101 & - 189 & -212 &,- 271 &,- 034 &,- 098 \\
\hline & Sig. (2-tailed) & 769 & & ,000 & , 000 & 129 & 125 & ,563 & 276 & 222 & 116 & ,846 & 577 \\
\hline & $\mathrm{N}$ & 35 & 35 & 35 & 35 & 35 & 35 & 35 & 35 & 35 & 35 & 35 & 35 \\
\hline \multirow[t]{3}{*}{ PBI } & $\begin{array}{l}\text { Pearson } \\
\text { Correlation }\end{array}$ & ,039 & $-.589^{* *}$ & 1 & $.515^{* *}$ & $.532^{* *}$ & -309 & -175 & 213 & $.349^{*}$ & $.426^{*}$ & $.542^{* *}$ & 155 \\
\hline & Sig. (2-tailed) & ,825 & ,000 & & , 002 & 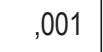 & 071 & 315 & 219 & ,040 & ,011 & , 001 ب ب & ,375 \\
\hline & $\mathrm{N}$ & 35 & 35 & 35 & 35 & 35 & 35 & 35 & 35 & 35 & 35 & 35 & 35 \\
\hline \multirow[t]{3}{*}{ BoP } & $\begin{array}{l}\text { Pearson } \\
\text { Correlation }\end{array}$ &,- 057 & $-.853^{* *}$ & $.515^{* *}$ & 1 & 211 & 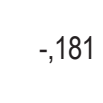 &,- 028 & ,099 & ,135 & ,222 & ,037 & 214 \\
\hline & Sig. (2-tailed) & ,744 & ,000 & ,002 & & 223 & ,299 & 875 & ,572 & 438 & 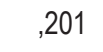 & ,834 & 218 \\
\hline & $\mathrm{N}$ & 35 & 35 & 35 & 35 & 35 & 35 & 35 & 35 & 35 & 35 & 35 & 35 \\
\hline \multirow[t]{3}{*}{ PD_Mean } & $\begin{array}{l}\text { Pearson } \\
\text { Correlation }\end{array}$ &,- 060 &,- 262 & $.532^{* *}$ & 211 & 1 & $-.552^{* *}$ & ,022 & 231 & $.376^{*}$ & $.572^{* *}$ & $.567^{* *}$ & 136 \\
\hline & Sig. (2-tailed) & ,732 & 129 & ,001 & 223 & & 001 & 899 & 182 & ,026 & ,000 & , 000 & 436 \\
\hline & $N$ & 35 & 35 & 35 & 35 & 35 & 35 & 35 & 35 & 35 & 35 & 35 & 35 \\
\hline \multirow[t]{3}{*}{$\mathrm{PD}<3 \mathrm{~mm}$} & $\begin{array}{l}\text { Pearson } \\
\text { Correlation }\end{array}$ & ,027 & 264 &,- 309 & -,181 & $-.552^{* *}$ & 1 & 142 & $-.665^{* *}$ & $-.524^{* *}$ & $-.576^{* *}$ &,- 276 &,- 059 \\
\hline & Sig. (2-tailed) & ,876 & ,125 & ,071 & ,299 & ,001 & & ,415 & ,000 & ,001 & ,000 & 108 & ,736 \\
\hline & $N$ & 35 & 35 & 35 & 35 & 35 & 35 & 35 & 35 & 35 & 35 & 35 & 35 \\
\hline \multirow[t]{3}{*}{$\mathrm{PD}=3-5 \mathrm{~mm}$} & $\begin{array}{l}\text { Pearson } \\
\text { Correlation }\end{array}$ & ,009 & 101 ب &,- 175 &,- 028 & ,022 & 142 & 1 & $-.707^{* *}$ & $-.491^{* *}$ &,- 093 &,- 109 & 100 \\
\hline & Sig. (2-tailed) & ,957 &, 563 & ,315 & ,875 & ,899 & ,415 & &, 000 & ,003 &, 596 &, 532 &, 570 \\
\hline & $\mathrm{N}$ & 35 & 35 & 35 & 35 & 35 & 35 & 35 & 35 & 35 & 35 & 35 & 35 \\
\hline \multirow[t]{3}{*}{$P D=5-7 m m$} & $\begin{array}{l}\text { Pearson } \\
\text { Correlation }\end{array}$ &,- 076 &,- 189 & 213 & 099 & 231 & $-.665^{* *}$ & $-.707^{* *}$ & 1 & 299 & ,262 & 137 & 019 \\
\hline & Sig. (2-tailed) & ,664 & 276 & ,219 &, 572 & , 182 & , 000 & ,000 & & ,081 & , 129 & ,433 & ,915 \\
\hline & $\mathrm{N}$ & 35 & 35 & 35 & 35 & 35 & 35 & 35 & 35 & 35 & 35 & 35 & 35 \\
\hline \multirow[t]{3}{*}{$\mathrm{PD}>7 \mathrm{~mm}$} & $\begin{array}{l}\text { Pearson } \\
\text { Correlation }\end{array}$ & ,080 &,- 212 & $.349^{*}$ & ,135 & $.376^{*}$ & $-.524^{* *}$ & $-.491^{* *}$ & ,299 & 1 & $.535^{* *}$ & $.335^{*}$ &,- 098 \\
\hline & Sig. (2-tailed) & 649 & ,222 & , 040 & ,438 & ,026 & ,001 & ,003 & ,081 & & ,001 & ,049 & ,577 \\
\hline & $\mathrm{N}$ & 35 & 35 & 35 & 35 & 35 & 35 & 35 & 35 & 35 & 35 & 35 & 35 \\
\hline
\end{tabular}




\begin{tabular}{|c|c|c|c|c|c|c|c|c|c|c|c|c|c|}
\hline \multirow[t]{3}{*}{ CAL, mm } & $\begin{array}{l}\text { Pearson } \\
\text { Correlation }\end{array}$ & ,034 &,- 271 & $.426^{*}$ & 222 & $.572^{* *}$ & $-.576^{* *}$ & - -093 & 262 & $.535^{* *}$ & 1 & $.711^{* *}$ & 209 \\
\hline & Sig. (2-tailed) & ,845 & 116 & 011 & 201 & , 000 & ,000 & ,596 & 129 & , 001 & & ,000 & ,229 \\
\hline & $\mathrm{N}$ & 35 & 35 & 35 & 35 & 35 & 35 & 35 & 35 & 35 & 35 & 35 & 35 \\
\hline \multirow[t]{3}{*}{$\begin{array}{l}\text { Bone loss, } \\
\mathrm{mm}\end{array}$} & $\begin{array}{l}\text { Pearson } \\
\text { Correlation }\end{array}$ & ,054 &,- 034 & $.542^{* *}$ & ,037 & $.567^{* *}$ &,- 276 & -109 & 137 & $.335^{*}$ & $.711^{1 *}$ & 1 & ,325 \\
\hline & Sig. (2-tailed) & ,757 & ,846 & ,001 & ,834 &, 000 & 108 & ,532 & ,433 & ,049 &, 000 & & ,056 \\
\hline & $\mathrm{N}$ & 35 & 35 & 35 & 35 & 35 & 35 & 35 & 35 & 35 & 35 & 35 & 35 \\
\hline \multirow[t]{3}{*}{ |L8 } & $\begin{array}{l}\text { Pearson } \\
\text { Correlation }\end{array}$ & $-.337^{*}$ & - & 155 & 214 & 136 &,- 059 & 100 & ,019 & - 1,098 & 209 & ,325 & 1 \\
\hline & Sig. (2-tailed) & ,048 & ,577 & ,375 & 218 & 436 & 736 & ,570 & 915 & 577 & 229 & 056 & \\
\hline & $\mathrm{N}$ & 35 & 35 & 35 & 35 & 35 & 35 & 35 & 35 & 35 & 35 & 35 & 35 \\
\hline
\end{tabular}

*. Correlation is significant at the 0.05 level (2-tailed).

**. Correlation is significant at the 0.01 level (2-tailed).

The analysis of the current assay established statistically significant correlation between:

1. HI and PBI - severity and HI and BOP-which shows that the reduction of free from plaque surfaces leads to increased bleeding on probing;

2. A significant correlation between PBI- severity and PD - average and Bone loss;

3. A strong correlation between BOP and Bone loss
4. The significant correlation between PD $3-5 \mathrm{~mm}$ and $\mathrm{PD} \geq 7 \mathrm{~mm}$ and $\mathrm{CAL}$ average, also a strong correlation between $\mathrm{PD} \geq 7 \mathrm{~mm}$ and bone loss.

5. Establishes a very high positive correlation between the CAL and Bone loss $(\mathrm{R}=0.71)$;

\section{Established differences between the two most common genotype - GT/TT and TT/TT}

Table 2. Statistically reliable differences found in patients with genotype GT/TT and TT /TT.

\begin{tabular}{|c|c|c|c|}
\hline \multirow[t]{2}{*}{ Variable } & Genotype GT/AT & Genotype TT/TT & \multirow{2}{*}{$\begin{array}{c}\text { P value } \\
\text { / Student t-test / }\end{array}$} \\
\hline & Mean & Mean & \\
\hline Patients, $\mathbf{N}$ & 23 & 8 & \\
\hline Age & 47 & 43 & 0.24 \\
\hline HI & 41365 & 12540 & 0.65 \\
\hline PBI & 30713 & 29252 & 0.80 \\
\hline BOP distribution & 97.12 & 94.81 & 0.44 \\
\hline PD mm & 47209 & 41365 & 0.54 \\
\hline PD $\leq 3 \mathrm{~mm} \%$ & 27.67 & 31.90 & $0.09 *$ \\
\hline $\mathrm{PD}=3 \div 5 \mathrm{~mm} \%$ & 36.23 & 36.18 & 0.99 \\
\hline $\mathrm{PD}=5 \div 7 \mathrm{~mm} \%$ & 26.77 & 25.91 & 0.83 \\
\hline $\mathrm{PD} \geq 7 \mathrm{~mm} \%$ & 12298 & 43836 & $0.09 *$ \\
\hline CAL mm & 44109 & 43895 & 0.63 \\
\hline Bone loss mm & 44046 & 44077 & 0.63 \\
\hline IL-8 pg/ml & 0.97 & 44044 & 0.96 \\
\hline
\end{tabular}


Fig. 1. Box plots representing the percentage of (a) $P D \leq 3 \mathrm{~mm}$ and (b) $P D \geq 7 \mathrm{~mm}$ in patients according to the different 6 genotypes (GT/AT, TT/TT, TT/AT, GG/AA, GG/TT, TT/AA). The upper and lower limits of the boxes represent the 75th and 25th percentiles respectively (the horizontal bar across the box indicates the median and the end of the vertical lines indicates the minimum and maximum data values). The results obtained can be interpreted that in both the genotype GT/TT and TT/ AT predominate moderately to deep periodontal pockets.
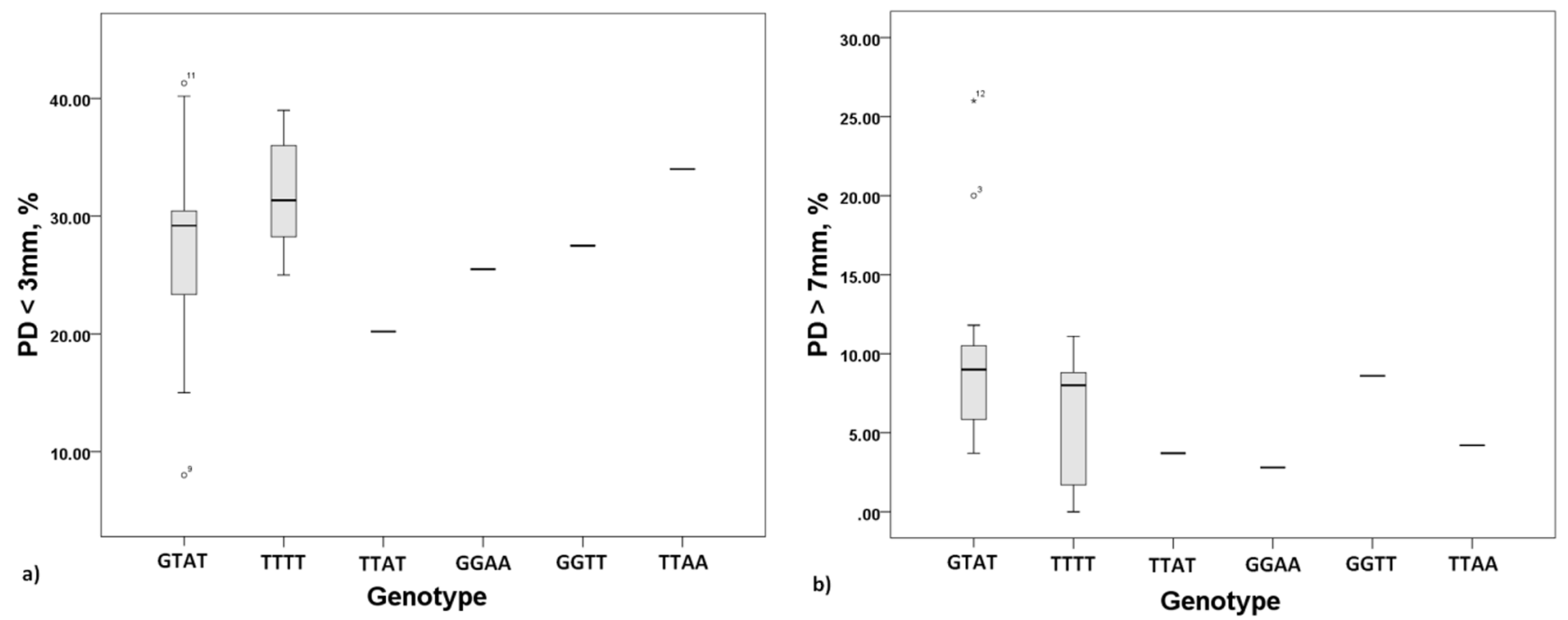

Table 3. Statistically reliable differences identified between the clinical indications for patients depending on gender.

\begin{tabular}{|c|c|c|c|}
\hline \multirow[t]{2}{*}{ VARIABLE } & FEMALE & MALE & \multirow{2}{*}{$\begin{array}{c}\text { P value } \\
\text { / Student t-test / }\end{array}$} \\
\hline & MEAN & MEAN & \\
\hline PATIENTS N & 23 & 8 & \\
\hline AGE & 46 & 46 & 0,85 \\
\hline HI & 5,39 & 1,74 & $0.06 *$ \\
\hline PBI & 2,77 & 3,06 & 0,11 \\
\hline BOP- distribution & 95,52 & 99 & $0.04 *$ \\
\hline PD mm & 4,15 & 4,5 & 0,16 \\
\hline $\mathrm{PD} \leq 3 \mathrm{~mm}, \%$ & 30,56 & 24,14 & $0.04 *$ \\
\hline $\mathrm{PD}=3 \div 5 \mathrm{~mm}, \%$ & 39,03 & 34,53 & 0,08 \\
\hline $\mathrm{PD}=5 \div 7 \mathrm{~mm}, \%$ & 24,02 & 29,65 & 0,11 \\
\hline $\mathrm{PD} \geq 7 \mathrm{~mm}, \%$ & 6,39 & 11,69 & $0.02 *$ \\
\hline CAL mm & 4,93 & 5,42 & $0.03 *$ \\
\hline Bone loss mm & 2,98 & 3,29 & 0,09 \\
\hline IL-8 pg/ml & 1,03 & 0,95 & 0,53 \\
\hline
\end{tabular}


Fig. 2. Box plots representing the (a) HI, (b) BOP distribution (c) percentage of PD $\leq 3 \mathrm{~mm}$, (d) percentage of PD $\geq 7 \mathrm{~mm}$, and (d) CAL in patients according to the different gender (male and female). The upper and lower limits of the boxes represent the 75 th and 25 th percentiles respectively; (the horizontal bar across the box indicates the median and the end of the vertical lines indicates the minimum and maximum data values).

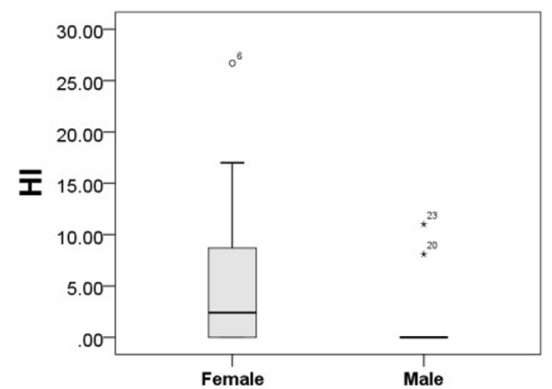

a) Gender

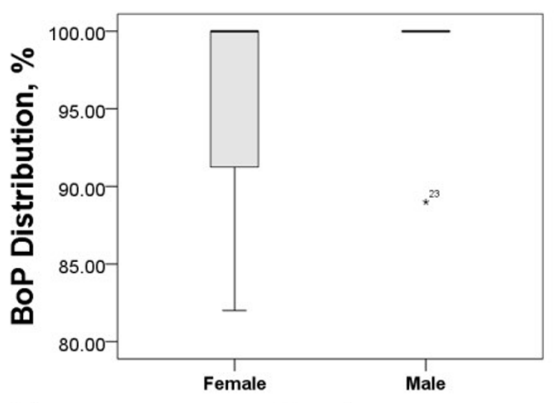

b)

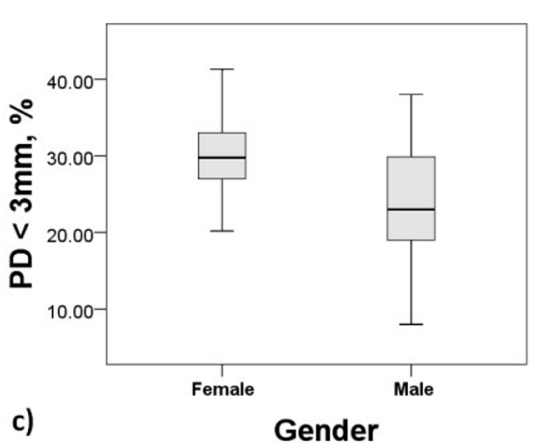

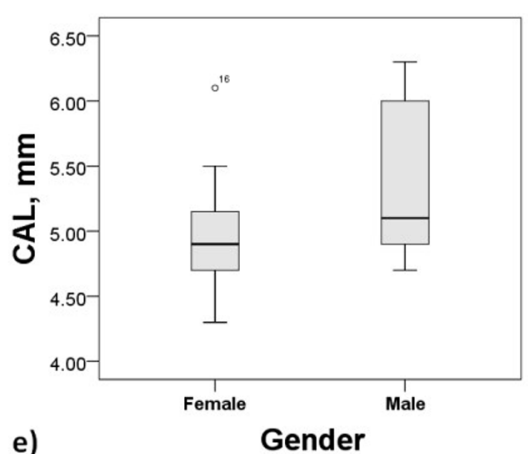

e)

Gender
DISCUSSION OF THE RESULTS:

In our study, we found a close relationship between the parameters of the periodontal status. The results have shown that the biggest relationship is observed between the presence of GT/AT and TT/TT genotype and distribution of PD 5-7 $\mathrm{mm}$ and $\mathrm{PD} \geq 7 \mathrm{~mm}(\mathbf{p}<\mathbf{0 . 0 9})$. It has been established that the distribution of BOP is higher in male patients $(\mathbf{p}<\mathbf{0 . 0 4})$. The higher distribution of shallow pockets $\mathrm{PD} \leq 3 \mathrm{~mm}$ is encountered in female patients $(\mathbf{p}<\mathbf{0 . 0 4})$. The bigger distribution of deep pockets $\mathrm{PD} \geq 7 \mathrm{~mm}$ is found in male patients $(\mathbf{p}<\mathbf{0 . 0 2})$.

Significant positive correlations were established between the loss of attachment as the main criterion of the severity of the periodontitis (CAL) and bone loss ( $\mathbf{p}=$ $\mathbf{0 . 0 0 0 1}$ ), and also between the loss of attachment and the deep periodontal pockets $\geq 7 \mathrm{~mm}(\mathbf{p}=\mathbf{0 . 0 0 1})$.

In the present research, the main goal was to establish the distribution of IL-8 gene polymorphism in locirs $4073(-251 \mathrm{~A} / \mathrm{T})$ and rs2227307 (-396T/G)in patients with chronic periodontitis. In the scientific literature, there's a discussion about this problem based on the insufficient number of investigations with opposing results [24-27]. In the group of patients investigated by us increased serum levels of IL-8average $169,91 \mathrm{pg} / \mathrm{ml}$ were established in most of all, analysed blood samples. Compared to other investigations, our study showed expressively higher values of the levels of the investigated IL-8 [28-30]. We could explain these results by analysing the objective clinical and paraclinical database, which characterize the investigated group as patients with severe chronic periodontitis and advanced tissue destructive processes [31]. For this reason, we think that the results achieved by us correctly reflect the severity of the clinical manifestation of the periodontal disease.

In this research 6 predominant genotypes of IL-8 for rs4073 (-251A/T) and rs2227307(-396T/G) were established: GT/AT, TT/TT, TT/AT, GG/AA, GG/TT и TT/AA, with the highest prevalence of GT/ AT genotype - $\mathbf{6 5 . 7 1}$ $\%$ and TT/TT genotype $\mathbf{- 2 2 . 8 6 \%}$.In compare to patients with GT/AT genotype, in patients with TT/TT genotype we established a strong correlation between the presence of IL-8 in serum and the values of HI\% ( $\mathbf{p = 0 . 0 2 8})$, and strong correlation between the presence of IL- 8 and BOP distribution. Statistically reliable differences in the predominant genotypes GT/AT and TT/TT and the percentage of distribution of PD 5-7 $\mathrm{mm}$ and $\mathrm{PD} \geq 7 \mathrm{~mm}(\mathbf{p}<\mathbf{0 . 0 9})$ were established.

The determination of present genetic factors and the biomarkers specifically related to them could help the clinician to choose the correct approach for prevention and control of periodontal disease in susceptible patients. It is suggested that the establishment of the dynamic interactions between the different cytokines and their level of expression in gingival fluid and blood serum could be a major factor for initiation of periodontal disease as a determinant for its severity and progression [11, 32-34]. 


\section{CONCLUSION:}

According to the achieved results, we could suggest that the monitoring of the cytokine production could be helpful for diagnostics of individuals with periodontal disease or susceptible to it. Because of the heterogeneous results achieved in the group investigated by us, we can definitely support the hypothesis that the presence of allele A for rs407 (-251A/T) and allele $\mathrm{G}$ for rs2227307 (-396T/G) is strongly related with expression of severe periodontitis.
It is important to be emphasized that except for gene polymorphisms, the severity of periodontitis is determined by other environmental factors and mainly by the dysbalance between the host response and the presence of periodontal pathogens.

\section{Acknowledgements:}

This work was supported by the Medical University of Sofia (Grant, Agreement No. D-101/2017)

\section{REFERENCES:}

1. Mlachkova A, Popova Chr, Kicheva M. [Severity of chronicperiodontitis inrelatedwithIL-1B gene.] Problems of Dental Medicine. 2001. 37 (1): 6-14.[in Bulgarian]

2. Popova Chr, DossevaV, Mlachkova A. Correlation of gene expression of main inflammatory cytokines and the severity of chronic periodontitis. J of IMAB.2014 JulSep;20(3):563-566. [Crossref]

3. Silva N, Abusleme L, Bravo D, Dutzan N, Garcia-Sesnich J, Vernal R, et al. Host Response Mechanisms in Periodontal Diseases. J Appl Oral Sci. 2015 May-Jun;23(3):329-55. [PubMed] [Crossref]

4. Ebersole JL, Nagarajan R, Akers D, Miller CS. Targeted salivary biomarkers for discrimination of periodontal health and disease(s). Front Cell Infect Microbiol. 2015 Aug 19;5:62. [PubMed] [Crossref]

5. Laine ML, Loos BG, Crielaard W. Gene polymorphisms in chronic periodontitis. Int J Dent. 2010; 2010: 324719. [PubMed] [Crossref]

6. Kornman KS, di Giovanni FS. Genetic variations in cytokine expression: a risk factor for severity of adult periodontitis. Ann Periodontol. 1998 Jul;3(1):327-38. [PubMed] [Crossref]

7. Karimbux NY, Saraiya VM, Elangovan S, Allareddy V, Kinnunen T, Kornman KS, et al. Interleukin-1 Gene Polymorphisms and Chronic Periodontitis in Adult Whites: A Systematic Review and Meta-Analysis. J Periodontol. 2012 Nov;83(11):1407-19. [PubMed] [Crossref]

8. Linhartova $\mathrm{P}$, Cernochova $\mathrm{P}$, Izakovicova Holla L. IL1 Gene Polymorphisms in Relation to External Apical Root Resorption Concurrent With Orthodontia. Oral Dis. 2013
Apr;19(3):262-70.

[Crossref]

9. Loos BG, John RP, Laine ML. Identification of Genetic Risk Factors for Periodontitis and Possible Mechanisms of Action. J Clin Periodontol. 2005; 32(Suppl. 6):159-79. [PubMed] [Crossref]

10. Nikolopoulos GK, Dimou NL, Hamodrakas SJ, Bagos PG. Cytokine Gene Polymorphisms in Periodontal Disease: A Meta-Analysis of 53 Studies Including 4178 Cases and 4590 Controls. J Clin Periodontol. 2008 Sep;35(9):754-67. [PubMed] [Crossref]

11. Talvan ET, Mohor C, Chisnoiu D, Cristea V, Câmpian RS. Expression of Interleukin (IL)-1â, IL-8, IL-10 and IL-13 in Chronic Adult Periodontitis Progression. Arch Med. 2017; 9(3):4. [Crossref]

12. Toker H, Gorgun EP, Korkmaz EM. Analysis of IL-6, IL-10 and NFêB Gene Polymorphisms in Aggressive and Chronic Periodontitis. Cent Eur J Public Health. 2017; 25(2):157-162. [Crossref]

13. Dosseva-Panova V, Mlachkova A, Popova Ch, Kicheva M. Evaluation of interleukin-6, Lymphotoxin-a and TNF-a gene polymorphisms in chronic periodontitis. J of IMAB. $2015 \mathrm{Jul}-$ Sep;21(3):868-875. [Crossref]

14. Duff W. Molecular genetics of cytokines: Cytokines in chronic inflammatorydisease. In: Thompson A, Ed. The cytokine handbook. 1994; 2nd edition: 21-30. London: Academic Press.

15. Preshaw PM, Taylor JJ. How has research into cytokine interactions and their role in driving immune responses impacted our understanding of periodontitis? J Clin Periodontol. 2011
Mar;38(Suppl 11):60-84. [PubMed] [Crossref]

16. Majumder P, Panda SK, Ghosh S, Kumar Dey S. Interleukin Gene Polymorphisms in Chronic Periodontitis: A Case-Control Study in the Indian Population. Arch Oral Biol. 2019 May;101:156-164. [PubMed] [Crossref]

17.McGee JM, Tucci MA, Edmundson TP, Serio CL, Johnson RB. The Relationship Between Concentrations of Proinflammatory Cytokines Within Gingiva and the Adjacent Sulcular Depth.1998 Aug; 69(8):865-71. [PubMed] [Crossref]

18. Michalowicz BS, Diehl SR, Gunsolley JC, Sparks BS, Brooks CN, Koertge TE, et al. Evidence of a Substantial Genetic Basis for Risk of Adult Periodontitis. J Periodontol. 2000 Nov;71(11):1699-707. [PubMed] [Crossref]

19. Teles R, Sakellari D, Teles F, Konstantinidis A, Kent R, Socransky S, et al. Relationships Among Gingival Crevicular Fluid Biomarkers, Clinical Parameters of Periodontal Disease, and the Subgingival Microbiota. $J$ Periodontol. 2010 Jan;81(1):89-98. [PubMed] [Crossref]

20. Guzeldemir-Akcakanat E, Sunnetci-Akkoyunlu D, Orucguney B, Cine N, Kan B, Yilmaz EB, et al. GeneExpression Profiles in Generalized Aggressive Periodontitis: A Gene Network-Based Microarray Analysis. $J$ Periodontol. 2016 Jan;87(1):58-65. [PubMed] [Crossref]

21. Huang W, He B-Y, Shao J, Jia $\mathrm{X}-\mathrm{W}$, Yuan Y-D. Interleukin-1b rs1143627 Polymorphism with Susceptibility to Periodontal Disease. Oncotarget. 2017 May 9;8(19):3140631414. [PubMed] [Crossref] 
22. Suzuki A, Ji G, Numabe Y, Ishii K, Muramatsu M, Kamoi K. Largescale investigation of genomic markers for severe periodontitis. Odontology. 2004; 92:43-47. [Crossref]

23. Venza I, Visalli M, Cucinotta M, De Grazia G, Teti D, Venza M. Proinflammatory Gene Expression at Chronic Periodontitis and PeriImplantitis Sites in Patients With or Without Type 2 Diabetes. J Periodontol. 2010 Jan;81(1):99-108. [PubMed] [Crossref]

24. Andia DC, de Oliveira NFP, Letra AM, Nociti FH. Jr, Line SRP, de Souza AP. Interleukin-8 Gene Promoter Polymorphism (rs4073) May Contribute to Chronic Periodontitis. $J$ Periodontol. 2011 Jun;82(6):893-9. [PubMed] [Crossref]

25. Heidari Z, Moudi B, Mahmoudzadeh-Sagheb H. Immunomodulatory Factors Gene Polymorphisms in Chronic Periodontitis: An Overview. BMC Oral Health. 2019 Feb 12;19(1):29. [PubMed] [Crossref]

26. Kim YJ, Viana AC, Curtis KMC, Perez Orrico SR, Cirelli JA, MendesJunior CT, et al. Association of
Haplotypes in the IL8 Gene With Susceptibility to Chronic Periodontitis in a Brazilian Population. Clin Chim Acta. 2010 Sep 6;411(17-18):1264-8. [PubMed] [Crossref]

27. Kim YJ, Viana AC, Curtis KMC, Orrico SRP, Cirelli JA, Mendes-Junior CT, et al. Association of Haplotypes in the IL8 Gene With Susceptibility to Chronic Periodontitis in a Brazilian Population. Clin Chim Acta. 2010 Sep 6;411(17-18):1264-8. [PubMed] [Crossref]

28. Chen X, Huang J, Zhong L, Ding C. Quantitative Assessment of the Associations Between interleukin-8 Polymorphisms and Periodontitis Susceptibility. J Periodontol. 2015 Feb; 86(2):292-300. [PubMed] [Crossref]

29. Houshmand B, Hajilooi M, Rafiei A, Bidgoli M, Soheilifar S. Evaluation of IL-8 Gene Polymorphisms in Patients With Periodontitis in Hamedan, Iran. Dent Res J (Isfahan). 2012 Jul;9(4):427-32. [PubMed]

30. Sippert EA, de Oliveira e Silva C, Visentainer JEL, Sell AM. Association of Duffy Blood Group Gene Polymorphisms with IL8 Gene in
Chronic Periodontitis. PLoS ONE. 2013; 8(12):e83286. [Crossref]

31. Linhartova PB, Vokurka J, Poskerova H, Fassmann A, Holla LI. Haplotype Analysis of interleukin-8 Gene Polymorphisms in Chronic and Aggressive Periodontitis. Mediators Inflamm. 2013; 2013:342351. [PubMed] [Crossref]

32. Khosropanah H, Sarvestani EK, Mahmoodi A, Golshah M. Association of IL-8 (-251 a/T) Gene Polymorphism With Clinical Parameters and Chronic Periodontitis. J Dent (Tehran). 2013 May;10(4):312-8. [PubMed]

33. Yucel-Lindberg T, Brunius G. Epidermal Growth Factor Synergistically Enhances interleukin-8 Production in Human Gingival Fibroblasts Stimulated With interleukin1 beta. Arch Oral Biol. 2006 Oct; 51(10):892-8. [PubMed] [Crossref]

34. Ni X-B, Jia C, Yu H-D, Li Y-Q, Zeng X-T, Leng W-D. Comprehensive Analysis of interleukin-8 Gene Polymorphisms and Periodontitis Susceptibility. Oncotarget. $2017 \mathrm{Jul} \mathrm{25;}$ 8(30):48996-49004. [PubMed] [Crossref]

Please cite this article as: Mlachkova A, Dosseva-Panova V, Popova C, Kicheva M. The presence of Il-8 gene polymorphism at $(-251 \mathrm{~A} / \mathrm{T})$ and $(-396 \mathrm{~T} / \mathrm{G})$ position is related with susceptibility to periodontitis development. $J$ of IMAB. 2020 Jul-Sep;26(3):3234-3240. DOI: https://doi.org/10.5272/jimab.2020263.3234

Received: 08/07/2019; Published online: 13/07/2020

\author{
Address for correspondence: \\ Velitchka Dosseva-Panova \\ Department of Periodontology, Faculty of Dental Medicine, Medical University \\ - Sofia, \\ 1, St. George Sofiiski str., 1431 Sofia, Bulgaria. \\ E-mail: vdosseva@yahoo.com
}

